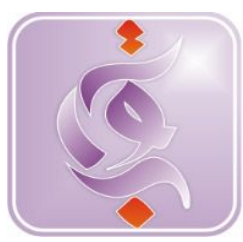

\title{
PROBLEM LANSIA DAN TINGKAT KEPUASANNYA DALAM MENGIKUTI KONSELING ISLAM
}

Received: 25 $5^{\text {th }}$ March 2019; Revised: 04 ${ }^{\text {th }}$ April 2019; Accepted: $22^{\text {th }}$ April 2019

Dr. Irman, S.Ag., M.Pd

Institut Agama Islam Negeri Batusangkar Email: irman@iainbatusangkar.ac.id

Dr. Silvianetri, M.Pd., Kons

Institut Agama Islam Negeri Batusangkar. Email: silvianetri@iainbatusangkar.ac.id

Zubaidah, M.Pd., Kons

Institut Agama Islam Negeri Bukittinggi

Email: zhubaidah09@gmail.com
Abstract. This study aims to reveal the problem of the elderly and determine the level of satisfaction of the elderly in attending counseling. The research method used is the mixed method desigh sequence, a combination of qualitative and quantitative approaches. Qualitative methods are used to explore problems experienced by the elderly and quantitative methods are used to determine the level of satisfaction of the elderly in following Islamic counseling. The research respondents were elderly who were in the Batusangkar Compassionate Nursing Home.

The results of the study found that the problem often experienced by the elderly in nursing homes is the inability to manage the mind and feelings to accept the reality. The effects of these problems are; (1) disruption of social interaction, (2) low self-existence, (3) despair, (4) feeling lonely, and (5) feeling guilty. To overcome these problems the elderly get Islamic counseling interventions. The level of satisfaction of the elderly towards Islamic counseling is high, both on aspects of the service process and on aspects of the results of counseling. Islamic counseling can be used to overcome various problems in the elderly.

Keywords : problem, satisfaction, counseling of Islamic.

\section{PENDAHULUAN}

Pembinaan lanjut usia (lansia) di panti jompo merupakan implementasi dari Undang-undang Dasar 1945. Fakir miskin dipelihara oleh negara (UUD 1945, Pasal: 34), dan setiap warga negara berhak atas pekerjaan dan penghidupan yang layak bagi dihadapinya sejalan dengan nilai-nilai Islam.Layanan konseling yang baik ditandai dengan kepuasan lansia setelah mengikuti konseling. Wismaningsih (2015: 29)Kepuasan merupakan gambaran harapan seseorang terhadap pelayanan ataupun jasa yang dirasakan apakah sesuai dengan harapan atau tidak. Jika dikaitkan dengan konseling, maka dapat dimaknai bahwa lansia akan merasa puas apabila proses konseling dan hasil konseling dapat memenuhi kebutuhan dan harapannya.

Tingkat kepuasan lansia sangat ditentukan oleh keprofesionalan konselor dalam memberikan layanan konseling. Gibson \& Mitchell (2011:258) menyatakan bahwa konselor yang melayani lansia harus 
mampu menunjukkan penerimaan, keterbukaan dan penghargaan terhadap klien dan nilai-nilai yang dianutnya. Artinya kepuasan lansia dalam mengikuti konseling terkait dengan kemampuan konselor dalam memberikan layanan dan penghargaan terhadap lansia tersebut.

\section{PROBLEM LANSIA}

Lansia di panti jompo tidak serta merta terlepas dari problem psikologis. Kuntjoro (2002:5) menjelaskan bahwa keadaan psikologi lansia mengalami penurunan yang berkaitan dengan fungsi kognitif dan psikomotor.Penurunan keadaan psikologis pada lansia akan memicu lahirnya masalah dalam kehidupannya.

BKKBN (2012:9) menyatakan bahwa masalah psikologis yang dialami lansia yaitu: Kecemasan dan ketakutan, mudah tersinggung, rasa kesepian, hilangnya kepercayaan diri, bermimpi tentang masa lampau, dan egois. Secara lebih rinci masalah yang sering muncul pada lansia yaitu: masalah kesepian. Lansia merasa kesepian karena jauh dari orang-orang yang dicintai. Ikasi (2014: 6) menyatakan adanya hubungan antara dukungan keluarga dengan tingkat kesepian lansia. Ada dua kesepian yang dialami lansia yaitu kesepian emosional dan sosial. Kesepian emosional pada diri lansia terjadi karena tidak adanya orang dicintai untuk mencurahkan kasih sayang. Sedangkan kesepian sosial timbul karena orang yang terdekat, sahabat dan masyarakat tempat bergaul dengannya sudah tidak ada lagi, karena dirinya berada di lingkungan panti.

Permasalahan lain yang dialami lansia yaitu rendahnya nilai-nilai spritual yang dimilikinya. Martin \& Osborn (1989) mengatakan bahwa kekosongan spiritual seringkali berakibat pada kesepian.Nilai spiritual menjadi penentu munculnya masalah kesepian yang dialami lansia. Tingkat kesepian yang dialami lansia menjadi penentu kondisi pisik dan psikis.

Masalah lansia selanjutnya adalah stress. Sunaryo (2004) menyatakan bahwa stress lansia adalah gangguan pada tubuh dan pikiran lansia yang disebabkan oleh perubahan dan tuntutan kehidupan, yang dipengaruhi oleh lingkungan maupun penampilan individu di dalam lingkungan. Stress yang dialami lansia memiliki efek pada psikis dan pisik. Yeniar dkk., (2010:87) menjelaskan dalam hasil penelitiannya bahwa tingkat stres yang di alami lansia di panti jompo dipicu adanya masalah tertentu, selanjutnya didapatkan data bahwa $81,25 \%$ lansia mengalami masalah berat, dan $18,75 \%$ lansia tersebut mengalami masalah ringan.

Stres bias terjadi karena ketidaksiapan lansia menerima perubahan yang ada pada lingungan baru. Indriana (2008:5) menyatakan bahwa ketidaksiapan dan upaya melawan arus perubahan-perubahan, justru menempatkan lansia pada posisi serba salah,yang akhirnya menjadi sumber akumulasi stress dan frustasi. Artinya stress yang terjadi pada lansia disebabkan oleh ketidaksiapan menerima perubahan untuk beradaptasi.

Masalah lansia selanjutnya adalah eksistensi diri. Kehidupan yang dilalui lansia di panti jompohanya sekedar untuk menghabiskan sisa hidup di hari tua, efek yang ditimbulkan adalah merasa diri tidak berharga. Wijayanti dkk (2007: 7) 
menyatakan bahwa lansia akan menghadapi masalah apabila kurang mendapatkan dukungan sosial dari keluarga. Perhatian anggota keluarga menjadi penting bagi lansia, sebagaimana firman Allah yaitu; jika salah seorang di antara keduanya atau kedua-duanya sampai berumur lanjut dalam pemeliharaanmu, maka sekali-kali janganlah kamu mengatakan kepada keduanya perkataan "ah" dan janganlah kamu membentak mereka dan ucapkanlah kepada mereka perkataan yang mulia (QS. Al Isra, 23).Bagi lansia yang terpisah dari keluarga dan kurang mendapatkan perhatian akan muncul masalah eksistensi diri yang akan berdampak pada kodisi psikologis dan pisik.

Berbagai persoalan yang dialami lansia, terutamaterkait dengan interaksi dan eksistensi diri, mengindikasikan bahwa pentingnya pemberian layanan konseling pada lansia. Melalui layanan konseling yang tepat akan berdampak positif pada aspek psikologis dan pisik lansia.

\section{KEPUASAN DALAM MENGIKUTI KONSELING ISLAM}

Kepuasan terkait dengan kognitif. Venhoven (2006:7) mengartikan kepuasan sebagai suatu perasaan yang timbul ketika membandingkan kehidupan yang dialami sekarang dengan kehidupan yang diinginkan, kepuasan ini bersifat kognitif.Konseling Islam yang dimaksud dalam kajian ini adalah konseling yang dibangun melalui nilai-nilai Islam. Sutoyo (2009:23) menguraikan bahwa konseling Islam adalah upaya membantu individu belajar mengembangkan fitrah dan atau kembali kepada fitrah, dengan cara memberdayakan iman, akal dan kemauan yang dikaruniakan Allah SWT. Hal ini dapat dipahami bahwa konseling Islam adalah suatu proses layanan untuk memberdayakan potensi yang dimiliki oleh konseli. Potensi tersebut terkait dengan kognitif, emosi dan perilaku.

Tujuan konseling Islam menurut Musnamar (1992) adalah untuk membantu klien menyelesaikan problem yang mengganggu mereka, mengembangkan beragam cara yang lebih positif untuk menyikapi hidup, menumbuhkan dan mengembangkan keterampilan pribadi, memecahkan masalah-masalah klien dan menumbuhkan kekuatan mereka dalam menyikapi hidup.

Pencapaian tujuan konseling dibutuhkan proses yang baik sesuai dengan tahapannya. Cormier \& Hackey (Gibson \& Mitchell, 1995:143) menyatakan bahwa ada empat tahapan konseling, yaitu: (1) membangun hubungan, (2) identifikasi masalah dan eksplorasi, (3) perencanaan pemecahan masalah dan aplikasi solusi, (4) pengakhiran. Tahapan konseling akan berjalan dengan baik, jika konselor bersikap dan bertingkah laku profesional.

Keprofesionalan konselor sangat menentukan tingkat kepuasan konseli, baik kepusan terhadap proses maupun kepuasan terhadap hasil konseling. Wismaningsih (2015: 30) meyatakan bahwa kepuasan merupakan gambaran harapan seseorang terhadap pelayanan ataupun jasa yang dirasakan apakah sesuai dengan harapan atau tidak.

Hal yang terkait dengan tingkat kepuasan lansian sebagi konseli, 
yaitukepuasan dalam proses konseling, berkenaan dengan kemampuan konselor dalam memberikan layanan yang baik dan penggunaan teknik yang tepat dalam proses konseling. Tingkat kepuasan konseling dapat dilihat dari tahapan-tahapan konseling yang dilalui konseli. Kepuasan proses konseling bagi lansia juga ditandai dengan sejauhmana lansia mengikuti proses konseling sesuai dengan harapannya.

Adapun yang dimaksud dengan kepuasan terhadap hasil konseling, yaitu sejauh mana proses konseling yang diikuti lansia dapat menyelesaikan masalah yang dihadapinya. Penyelesaian masalah yang dimaksud adalah lansia merasakan hasil konseling sesuai dengan harapannya. Kepuasan dalam mendapatkan layanan konseling sangat penting untuk pengentasan masalah yang dialami lansia.

\section{METODE PENELITIAN}

Metode penelitian yang digunakan adalah mixed method desigh sequence, merupakan kombinasi antara pendekatan kuantitatif dan kualitatif yang digunakan secara terpadu. Melalui metode ini diharapkan nantinya dapat menghasilkan pemahaman yang lebih baik terhadap masalah penelitian dibandingkan hanya menggunakan salah satu pendekatan saja.

Pendekatan kualitatif digunakan untuk menggali problem yang dialami lansia. Moleong (2006) menjelaskan bahwa pada penelitian kualitatif sumber data dan datanya bersifat naturalistik. Lincoln\&Guba (1985) menyatakan bahwa instrumen dalam penelitian kualitatif adalah manusia. Adapun yang dimaksud manusia adalah penelitiyang menjadi instrumen penelitian.
Teknik pengumpulan data menggunakan deep Interview dan uji keabsahan data dengan menggunakan teknik tri anggulasi. Secara spesifik peneliti mendalami penelitian melalui metode fenomenologi, yang dilakukan untuk menjelaskan, menafsirkan dan merumuskan tindakan manusia dengan cara menggambarkan struktur-struktur dasar, realita yang tampak nyata, disetiap orang yang berpegang teguh pada sikap alamiah. (Stake, 2010, \& Bogdan, 1982).

Pendekatan kuantitatif peneliti gunakan untuk melihat tingkat kepuasan lansia dalam mengikuti konseling Islam. Desain penelitian menggunakan single subject design. Barlow \& Hersen(1984)menyatakan bahwa single subject design dikenal juga dengan single caseexsprimental design, small-n design, single system designs, yangmerupakan jenis penelitian eksperimen yang mengkaji hubungan kausal. Desain penelitian diawali dengan pretest kemudian diberikan perlakuan, selanjutnya diberi posttest untuk melihat pengaruh dari perlakuan yang diberikan (Sugiyono, 2010:74, Johnson \& Christensen, 2004).

Subjek penelitian sebanyak 5 oranglansia yang ada di Panti Sosial Tresna Werda Kasih Sayang Ibu Batusangkar, yang diambil berdasarkan porpusive random sampling. Untuk alat pengumpul data, peneliti menggunakan instrumen yaitu Skala Kepuasan Lansia dalam mengikuti Konseling Islam. Analisis data yang digunakan yaitu analisis grafis.

\section{HASIL PENELITIAN}

Hasil penelitian mengungkapkan dua hal, yaitu masalah yang dialami oleh lansia 
dan tingkat kepuasan lansia dalam mengikuti konseling Islam. Adapun masalah yang ditemui lansia yaitu; Pertama, problem hubungan sosial yang kurang baik, di antaranya problem antara teman sekamar yang dilatarbelakangi oleh ketidakpedulian terhadap aturan kamar yang ada, dan kesalahpahaman dan sikap egois. Selanjutnya problem teman diluar kamar, hal ini dipicu oleh ketidakstabilan emosi di antara lansia, sehingga sering ada perasaan marah dan tersinggung, selanjutnya permasalahan juga disebabkan oleh perasaan cemburu diantara lansia terhadap orang yang disanyanginya. Beberapa permasalahan yang diuraikan di atas memicu timbulnya interaksi yang tidak harmonis dikalangan lansia, baik dengan teman sekamar maupun dengan teman diluar kamar.

Problem yang kedua adalah rendahnya eksistensi diri, ditandai dengan perasaan diri tidak berguna, menjadi beban keluarga, rasa malu. Setelah didalami akar permasalahan yang sesungguhnya, rendahnya eksistensi diri ini disebabkan karena keluarga kurang peduli dengan diri lansia, pandangan negatif orang lain terhadap lansia yang tinggal di panti jompo, karena dianggap orang buangan. Penyebab selanjutnya adalahkurangnya penghargaan yang diterima ketika bertemu dengan sahabat lama. Problem ini menjadikan lansia murung, tidak bersemangat dan sensitif.

Problem yang ketiga adalah putus asa dan ketidakberdayaan menjalani kehidupan. Lansia merasa bahwa hidupnya tidak berguna lagi, orang yang dicintai selama ini tidak lagi memperhatikan dirinya. Sedangkan sahabat yang selalu dekat dengannya satu persatu sudah mulai menjauh dari dirinya. Hal yang selalu membuat tak berdaya adalah keadaan kondisi pisik yang sakit-sakitan. Kondisi negatif tersebut menjadikan lansia berputus asa dan tidak punya harapan yang jelas dalam meneruskan kehidupan.

Problem yang keempat yaitumerasa kesepian, hal ini merupakan kondisi yang banyak muncul dikalangan lansia. Kesepian dirasakan ketika jauh dari orang yang dicintai, tidak mendapatkan kasih sayang dan perhatian. Rasa kesepian juga muncul akibat dari ketidakmampuan menyesuaikan diri dengan lingkungan baru dan ketidakmampuan memahami orang lain. Perasaan sepi memunculkan tindakan menjauhi orang laindan interaksi yang buruk dengan orang lain.

Problem yang kelima yaitumerasa berdosa, problem ini muncul dilatar belakangi ketidakmampuan memberikan nafkah kepada keluarga, menelantarkan anak sehingga hidupnya tidak beruntung dan mementingkan diri sendiri. Problem rasa berdosa ini selalu menghantui lansia bahwa dirinya tidak diampuni oleh Allah sebelum keluarga memberi maaf. Ketika diajak untuk mendekatkan diri kepada Allah lansia menjawab tetap tidak nyaman. Perasaan berdosa ini yang membuat lansia kurang tidur, makan tidak enak dan bahkan takut akan datangnya kematian. Efeknya lansia mengalami kegelisahan yang tiada ujungnya.

Berdasarkan beberapa temuan di atas, permasalahan yang dialami oleh lansia disebabkan oleh ketidakmampuan lansia mengelola pikiran dan perasan untuk menerima kenyataan yang ada. Efek yang ditimbulkan interaksi sosial terganggu, murung, sensitif, perasaan hampa dan gelisah.

Hasil penelitian selanjutnya yaitu terkait dengan tingkat kepuasan lansia dalam mengikuti konseling Islam. Tingkat kepuasan lansia dilihat dari dua aspek, yaitu aspek proses konseling dan aspek hasil konseling. Adapun tingkat kepuasan lansia 
pada aspek proses konseling terdapat pada Gambar1 berikut.

Gambar 1

Kepuasan Lansia pada Aspek Proses Konseling

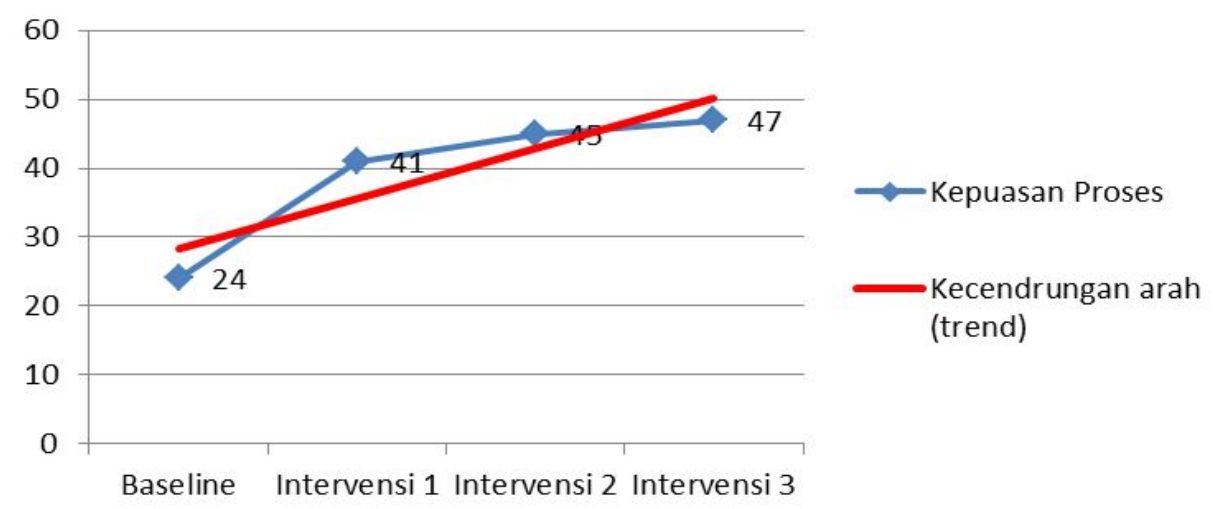

Berdasarkan Gambar 1 di atas, dapat dijelaskan bahwa tingkat kepusan lansia pada aspek proses konseling memiliki kecendrungan arah meningkat. Pada tahap baseline, trend kepuasan lansia berada pada kategori rendah dengan nilai skor rata-rata 24 poin. Pada intervensi 1, trend kepuasan lansia berada pada kategori tinggi dengan nilai skor rata-rata 41 poin. Selanjutnya intervensi 2, diperoleh trend kepuasan lansia berada pada kategori sangat tinggi dengan nilai skor rata-rata 45 poin. Adapun intervensi 3, diperoleh trend kepuasan lansia berada pada kategori sangat tinggi dengan nilai skor rata-rata 47 poin.

Berdasarkan analisis grafis di atas, dapat disimpulkan bahwa tingkat kepuasan lansia pada aspek proses konselingmemiliki trend positif, yaitu penerapan konseling Islamdapat meningkatkan kepuasan lansia pada aspek proses layanan. Artinya konseling lslam sangat baik diterapkan pada lansia, karena membawa kepuasan bagi lansia yang menerima intervensi. Sedangkan tingkat kepuasan lansia pada aspek hasil konseling terdapat pada gambar2 berikut. 
Gambar 2

Kepuasan Lansia pada Aspek Hasil Konseling

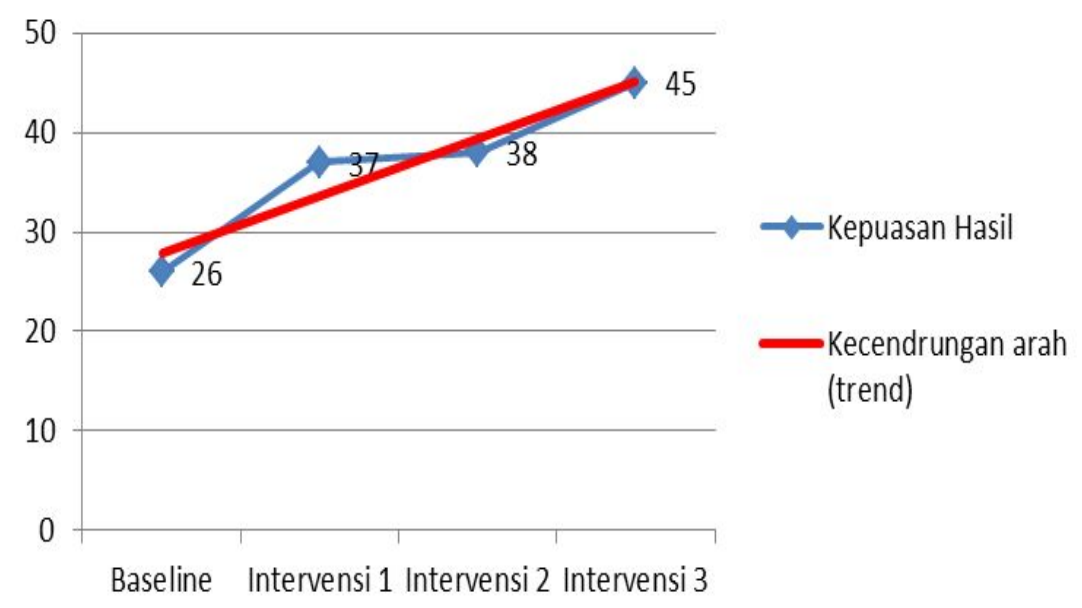

Berdasarkan Gambar 2 di atas, dapat dilihat bahwa tingkat kepuasan lansia pada aspek hasil konseling memiliki trend meningkat. Pada tahap baseline, diperoleh trend kepuasan lansia pada kategori rendah dengan nilai skor rata-rata 26 poin. Pada intervensi 1, trend kepuasan lansia berada pada kategori tinggi dengan nilai skor ratarata 37 poin. Selanjutnya intervensi 2, diperoleh trend kepuasan lansia berada pada kategori tinggi dengan nilai skor rata-rata 38 poin. Sedangkan intervensi 3, diperoleh trend kepuasan lansia berada pada kategori sangat tinggi dengan nilai skor rata-rata 45 poin. Berdasarkan analisis grafis, tingkatkepuasan lansia pada aspek hasil konseling memiliki trend positif. Artinya konseling Islam efektif untuk intervensi dalam mengentaskan masalah yang dialami lansia.

\section{PEMBAHASAN}

Lanjut usia (lansia) merupakan salah satu tahap perkembangan manusia, yang mesti dilalui oleh orang yang berumur 65 tahun ke atas. Tak jarang pada lansia timbul berbagai permasalahan. Atkinson et al., (1991:145) mengungkapkan bahwa usia di atas 65 tahun membawa masalah baru, di antaranya penurunan kekuatan fisik, merasa kurang dibutuhkan dan dihargai, dan merasa kesepian. Hampir bersamaan dengan itu Gibson \& Michell (2011:257) menguraikan bahwa masalah-masalah yang dialami oleh lansia adalah kehilangan pasangan, menurunnya kemampuan dan kenyamanan fisik dan mental, menurunnya keamanan finansial, menurunnya mobilitas (kesempatan untuk bergerak bebas), menurunnya kontak sosial, kesepian, dan meningkatnya gangguan kesehatan. Annisa \& Ifdil (2016: 93) menyatakan salah satu masalah psikologis yang sering terjadi pada lansia dalam kehidupan sosial adalah kecemasan.

Masalah-masalah yang dialami oleh lansia perlu dicarikan solusinya, sehingga lansia dapat menjalani hari tua yang lebih bermakna. Atkinson et al., (1991:145) mengungkapkan bahwa usia tua merupakan saat kontemplasi (merenung), jika berhasil 
menangani masalah yang timbul maka akan mendapatkan perasaan integritas (utuh). Elfiky (2007:159) mengungkapkan bahwa perenungan yang baik adalah disertai dengan afirmasi.

Cara yang lebih efektif untuk mengentaskan permasalahan yang dialami oleh lansia adalah melalui konseling. Gibson \& Michell (2011:258) berpendapat bahwa konselor sangat berperan dalam menyelesaikan permasalahan yang dialami manula melalui program-program layanan komunitas dan penjangkauanyang disebut juga dengan konseling populasi khusus. Salah satu layanan yang bisa membantu para manula adalah melalui layanan konseling individual. Selanjutnya Gibson \& Michell (2011:51) mengungkapkan bahwa konseling individual merupakan aktivitas inti dalam bidang konseling yang berpusat pada klien, berfokus pada pertumbuhan dan penyesuaian pribadi.

Konseling individual yang dimaksud adalah melalui pendekatan konseling Islam. Lubis (2007:97) menyebutkan bahwa konseling Islam adalah proses konseling yang bertujuan pada pendidikan Islam, membangun kehidupan sakinah, kehidupan yang tidak hanya sekedar mencapai kemakmuran tetapi juga mencapai ketentraman hidup spritual.

Konseling Islam format individual diharapkan turut ikut menyelesaikan permasalahan yang dialami lansia, sehingga para lansia di harapkan hidup lebih bermakna, hal ini merupakan dampak positif dari hasil konseling Islam. Dampak positif selanjutnya adalah adanya kepuasan lansia dalam proses konseling Islam, karena proses konseling penuh dengan rasa empatiyang selama ini adalah hal langka bagi konseli jompo. Konselor yang efektif adalah jika konselor dapat bersikap empati. Corey (2009:15-16) mengungkapkan bahwa ciriciri konselor yang efektif adalah mempunyai identitas diri, tulus, jujur, humor, melibatkan diri langsung dalam proses konseling (empati).

\section{KESIMPULAN}

Temuan masalah yang dialami lansia di panti jompo adalah ketidak mampuan mengelola pikiran dan perasan untuk menerima kenyataan yang ada. Efek yang ditimbulkan adalah : (a) interaksi sosial terganggu, (b) rendahnya eksistensi diri, (c) putus asa, (d)merasa kesepian, dan (e) merasa berdosa. Masalah tersebut diatasi dengan konseling Islam.Tanggapan lansia dalam mengikuti konseling Islam yaitu memiliki trend positif, dengan tingkat kepuasan tinggi baik pada aspek proses layanan maupun padaaspek hasil konseling. Lansia merasakan bahwa melalui konseling Islam mereka dapat menyelesaikan berbagai permasalahannya dan dapat menjalani hidup yang lebih bermakna.

\section{DAFTAR PUSTAKA}

Al-Qur'an.

Annisa, D. F., \& Ifdil. (2016). Konsep Kecemasan (Anxiety) pada Lanjut Usia (Lansia). Jurnal Konselor, 5(2), 93-99.

Atkinson, R.L., Atkinson R.C.,\& Hilgard, E.R. (1991). Pengantar Psikologi. Jakarta: Penerbit Erlangga.

Barlow, D.H.\& Hersen, M. (1984). Single Case Experimental Designs: 
Strategies for studying behavior change. New York: Pergamon Press.

BKKBN. (2012). Pembinaan Mental Emosional Bagi Lansia. Jakarta: Direktorat Bina Ketahanan Keluarga Lansia dan Rentan Badan Kependudukan dan Keluarga Berencana Nasional.

Bogdan, R. (1982). Qualitative Research For Education. Boston: Massahussets.

Corey, G. (2009). Theory and Practice of Counseling and Psychoterapy. New York: Thomson Books Cole.

Elfiky, I. (2000). Neuro Linguistic Programming. Canada: Canadian Traning Centre.

Gibson, R. L., \& Mitchell, M. H. (1995). Introduction to Guidance. New York: Macmillan Publisher.

Gibson, R. L., \& Mitchell, M.H. (2011).Bimbingan dan konseling.Yogyakarta: Pustaka Pelajar.

Ikasi, A., Jumaini., \& Hasanah, O. (2014). Hubungan Dukungan Keluarga Terhadap Kesepian (Lonelinnes) Pada Lansia. JOM PSIK, 1(2), 1-10.

Indriana, Y. 2008. Gerontologi: Memahami Kehidupan Usia Lanjut. Semarang: Universitas Diponegoro Press.

Indriana, Y., Kristiana, I. F., Sonda, A. A., \& Intanirian, A. (2010). Tingkat Stres Lansia di Panti Werdha Puncang Gading Semarang. Jurnal Psikologi Undip, 8 (2): 87-97.

Johnson, B., \&Christensen, L. (2004).DucationalResearch Quantitative, Qualitative and Mixed
Approaches. New York: Person Press.

Lincoln, Y. S., \& Guba, E. G. (1995) Naturalistic inquiry.Beverly Hills: Sage Publications.

Lubis, S. A. (2007). Konseling Islami. Yogyakarta: Elsaq Press.

Mangoenprasodjo, A.S. (2005). Mengisi Hari Tua dengan Bahagia. Jakarta: Pradipta Publishing.

Martin \& Osborn. J.G. 1989. Psychology Adjustment and Everyday Living. New Jersey: Prentice Hall Inc.

Musnamar, T. (1992).Dasar-dasar Konseptual Bimbingan dan Konseling Islami. Yokyakarta: UII Prees.

Moleong, L.J. 2006. Metode Penelitian Kualitatif. Bandung: Remaja Rosda Karya Press.

Stake, R.E. 2010. Qualitative research. New York: Guilford Publications.

Santrock, W.J. (2002). Life Span Development. Jakarta: Erlangga Press.

Sugiyono. (2010). Metode Penelitian Kuantitatif Kualitatatif dan $R \& D$. Bandung: Alfabeta.

Sunaryo. (2004). Psikologi untuk Keperawatan. Jakarta: EGC.

Sutoyo, A. (2007). Bimbingan dan Konseling Islami. Semarang: Cipta Prima Nusantara.

Veenhoven, R. 2006. New Direction in the Study of Happiness. USA: University of Notre Dame Press.

Wijayanti, R., Sahar, J., \& Sutanto.(2007). Hubunganantara dukungan keluarga melalui interaksi sosial, upaya penyediaan transportasi, 
11 Jurnal Al-Qalb, Jilid 10, Nomor 1, Maret 2019, hlm.1-11

finansial dan dukungan dalam menyiapkan makanan dengan respon kehilangan pada lansia di desa pekaja, kalibagor, kabupaten banyumas. Jurnal keperawatan Soedirman, vol. 2(1), 1-7.
Wismaningsih, E. R. (2015). Hubungan Pelayanan Posyandu X Dengan Tingkat Kepuasan Lansia. Jurnal Wiyata, Vol. 2(1), 29-33. 